\title{
GAMBARAN UMUR DAN PARITAS IBU YANG MENGALAMI ABORTUS DI WILAYAH KERJA PUSKESMAS CIAWI TAHUN 2012.
}

oleh :

Ayu Rosita, SST, M.Kes

A. Abstrak

Aborsi telah dilakukan oleh 2,3 juta perempuan. Diperkirakan diseluruh dunia setiap tahun terjadi 40-70 aborsi per 100 wanita usia produktif. Umur ibu merupakan salah satu faktor resiko terjadinya abortus, dalam kurun reproduksi sehat dikenal bahwa usia aman dalam kehamilan, persalinan dan kelahiran yaitu 20-35 tahun. Berdasarkan data yang diperoleh dari Puskesmas Ciawi pada tahun 2011 ditemukan jumlah kejadian abortus sebanyak 71 kasus. Tujuan penelitian adalah Gambaran umur dan paritas ibu yang mengalami abortus di Wilayah Kerja Puskesmas Ciawi Tahun 2012.

Jenis penelitian yang digunakan adalah penelitian kuantitatif dengan metode deskriptif. Populasi dalam penelitian adalah seluruh ibu yang mengalami abortus di wilayah PKM DTP Ciawi tahun 2011 yang berjumlah 71 orang. Intrumen dalam penelitian ini menggunakan data yang diambil dari laporan Poned PKM Ciawi tahun 2011. Analisis data dalam penelitian ini adalah analisis univariat. Analisis ini menghasilkan distribusi frekuensi untuk menggambarkan tiap-tiap variabel yang akan diteliti

Hasil penelitian adalah sebagian besar ibu hamil yang mengalami abortus di wilayah PKM DTP Ciawi tergolong umur 20-35 tahun, serta sebagian besar ibu hamil yang mengalami abortus di PKM DTP Ciawi termasuk nullipara.

Kesimpulan dan saran dalam penelitian ini adalah sebagian besar ibu hamil yang mengalami abortus di wilayah PKM DTP Ciawi tergolong umur 20-35 tahun, serta sebagian besar ibu hamil yang mengalami abortus di PKM DTP Ciawi termasuk nullipara. Sehingga dibuat saran yang direkomendasikan adalah Diharapkan Puskesmas lebih meningkatkan pemahaman masyarakat terhadap masalah kesehatan reproduksi khususnya asuhan selama kehamilan melalui konseling, penyuluhan dan pemberdayaan posyandu. Pihak Puskesmas mencari faktor utama penyebab kejadian abortus pada ibu hamil.

\section{Kata Kunci: Abortus, Umur, Paritas}




\section{B. Latar belakang}

Angka Kematian lbu (AKI) di Indonesia masih tinggi. Menurut Survei Demografi dan Kesehatan Indonesia (SDKI) 2007, AKI di Indonesia adalah 228 per 100.000 kelahiran hidup. Ada 3 penyebab klasik kematian ibu yaitu perdarahan, keracunan kehamilan dan infeksi. Menurut Organisasi Kesehatan Dunia (WHO) 15-50\% kematian ibu disebabkan oleh abortus. Abortus berdampak perdarahan atau infeksi yang dapat menyebabkan kematian.

Aborsi telah dilakukan oleh 2,3 juta perempuan. Diperkirakan diseluruh dunia setiap tahun terjadi 40-70 aborsi per 100 wanita usia produktif. Umur ibu merupakan salah satu faktor resiko terjadinya abortus, dalam kurun reproduksi sehat dikenal bahwa usia aman dalam kehamilan, persalinan dan kelahiran yaitu 20-35 tahun. (Wheeler L, 2004).

Penyebab peristiwa ini amat beragam, sebagian besar tidak diketahui. Pada trimester pertama, penyebab

\section{Metode}

Jenis penelitian yang digunakan adalah penelitian kuantitatif dengan metode deskriptif . Populasi dalam penelitian adalah seluruh ibu yang mengalami abortus di wilayah PKM DTP Ciawi tahun 2011 yang berjumlah 71 orang. Dalam penelitian ini peneliti akan menggunakan data sekunder dimana peneliti akan melihat langsung catatan rekam medik tentang usia ibu dan paritas ibu yang mengalami abortus di PKM DTP Ciawi.

Instrumen dalam penelitian ini menggunakan data yang diambil dari laporan Poned PKM Ciawi tahun 2011. Pengolahan Data

a. Editing

Pada tahap editing dilakukan penyuntingan data untuk mencegah terjadinya kesalahan atau adanya kuesioner yang belum lengkap, diantaranya mengecek apakah semua utama abortus spontan adalah kelainan kromosom yang berarti bahwa ada masalah dengan kromosom mudigah. Kelainan kromosom dapat terjadi pada sel sperma, sel telur atau saat pembelahan zygote. Penyebab abortus spontan yang lain adalah : Masalah hormonal, infeksi atau kesehatan ibu, Gaya hidup (merokok, penyalahgunaan obat, malnutrisi, caffein, paparan, terhadap radiasi atau bahan beracun), Proses implantasi hasil konsepsi kedalam endometrium yang tidak berlangsung secara sempurna, Usia ibu, serta Trauma ibu.

Sedangkan dampak aborsi adalah kematian bagi bumil dan janinnya bila dilakukan oleh mereka yang tidak terlatih, perdarahan yang terus menerus dan dapat mengakibatkan infeksi, Berdampak pada kondisi psikologis serta perasaan bersalah yang menghantui sang ibu.

Berdasarkan data yang diperoleh dari Puskesmas Ciawi pada tahun 2011 ditemukan jumlah kejadian abortus sebanyak 71 kasus.

kolom sudah semuanya terisi.

b. Entry data

Memasukan data ke dalam program komputer untuk ditampilkan dalam bentuk tabel serta dianalisis dalam bentuk narasi.

c. Coding

Coding adalah mengklasifikasikan umur responden kedalam kategorikategori biasanya klasifikasi di lakukan dengan cara memberi tanda atau kode bentuk angka pada masing-masing jawaban.

d. Tabulating

Data yang telah diskor kemudian ditabulasikan dan disajikan dalam bentuk tabel distribusi.

Analisis Data

Analisis data dalam penelitian ini adalah analisis univariat. Analisis ini menghasilkan distribusi frekuensi untuk menggambarkan tiap-tiap variabel yang akan diteliti. Sebelum dilakukan analisis data, terlebih dahulu dilakukan pengolahan 
data secara manual untuk setiap item yang dijawab benar diberi satu dan jika jawaban yang salah atau tidak di isi diberi skor nol. Selanjutnya dilakukan perhitungan dari

\section{Hasil penelitian}

\section{Jenis Abortus}

Tabel menunjukan bahwa sebagian besar kasus abortus yang terjadi di Wilayah Kerja PKM DTP Ciawi merupakan abortus provokatus yaitu 68 kasus atau 95,78 \%, dan sebagian kecil merupakan abortus spontan yaitu 3 kasus atau $4.22 \%$.

2. Penyebab Abortus

Tabel menunjukan bahwa sebagian besar kasus abortus yang terjadi di Wilayah Kerja PKM DTP Ciawi disebabkan oleh kecapean yaitu 66 kasus $(92.95 \%)$. Dan yang lainnya disebabkan oleh Toxoplasma 1 kasus (1.41\%),

\section{E. Pembahasan}

\section{Umur}

Penelitian menyatakan bahwa sebagian besar ibu yang mengalami abortus di wilayah kerja PKM Ciawi adalah yang berusia 20-35 tahun yaitu sebanyak 46 orang $(64,79 \%)$. Hal ini tidak sesuai dengan teori yang menyatakan bahwa usia merupakan salah satu penyebab terjadinya abortus. Menurut Manuaba (1998), dimana umur kurang dari 20 tahun dan umur diatas 35 tahun merupakan salah satu factor kehamilan dengn risiko tinggi.

Menurut Cunningham

frekuensi abortus bertambah dari $12 \%$ pada wanita yang berusia kurang dari 20 tahun, menjadi $26 \%$ pada wanita berumur diatas 40 tahun. Pada usia diatas 35 tahun telah terjadi sedikit penurunan denyut jantung yang disebabkan oleh berkembangnya

kontraksi

miokardium sehingga sirkulasi dan pengambilan $\mathrm{O}_{2}$ oleh darah di paru-paru juga mengalami penurunan, ditambah lagi dengan peningkatan tekanan darah dan penyakit lainnya yang melemahkan hasil penelitian dengan menggunakan rumus interval (Somantri : 2007).

Blighted ovum 1 kasus (1.41\%), jatuh dari motor 1 kasus (1.41\%), Penyakit TB 1 kasus $(1.41 \%)$.

3. Umur Penderita abortus

Data menunjukan bahwa sebagian besar ibu yang mengalami abortus di wilayah kerja PKM DTP ciawi adalah berusia 2035 tahun yaitu sebanyak 46 orang $(64,79 \%)$. dan sebagian kecil berumur $<20$ tahun yaitu sebanyak 11 orang (15.49).

4. Paritas Penderita abortus

Data menunjukan bahwa sebagian besar ibu yang mengalami abortus di wilayah kerja PKM DTP Ciawi termasuk nullipara yaitu 33 orang (46.48).

kondisi ibu, sehingga mengganggu sirkulasi darah ibu ke janin. hal ini akan mengganggu pertumbuhan dan perkembangan hasil konsepsi, dimana hasil konsepsi tidak dapat berimplantasi secara maksimal yang mengakibatkan kematian atau lepasnya sebagian atau seluruh dari hasil konsepsi dari tempat implantasi. bagian yang terlepas ini dianggap benda asing oleh uterus sehingga uterus berusaha untuk mengeluarkannya dengan cara berkontraksi (Multazamiah, 2003).

Akan tetapi terdapat penelitian yang serupa dimana $29,7 \%$ abortus terjadi pada usia 25 - 35 tahun. Hal ini dimungkinkan karena faktor pendukung lain seperti pergeseran sosial, moral serta ekonomi. (Kodim : 2011)

\section{Paritas}

Berdasarkan hasil penelitian menunjukan bahwa dari keseluruhan responden yang diteliti 33 orang $(46,48 \%)$ termasuk kategori nullipara, dan 22 orang $(30.99 \%)$ berstatus multipara dan bahkan 2 orang (2.81\%) sudah berstatus grandemultipara.

Menurut Wiknjosastro tahun2005 
paritas adalah jumlah anakyang telah dilahirkan ibu baik dalam kondisi sehat maupun meninggal. Penelitian ini sesuai dengan teori paritas 1 dan tinnggi (lebih dari 3 mempunyai angka kematian maternal lebih tinggi.

\section{F. Simpulan dan saran}

Berdasarkan hasil penelitian dapat disimpulkan :

1. Sebagian besar ibu hamil yang mengalami abortus di wilayah PKM DTP Ciawi tergolong umur 20-35 tahun.

2. Sebagian besar ibu hamil yang mengalami abortus di PKM DTP Ciawi termasuk nullipara.

Saran

Diharapkan Puskesmas lebih meningkatkan pemahaman masyarakat terhadap masalah kesehatan reproduksi khususnya asuhan selama kehamilan melalui konseling, penyuluhan dan pemberdayaan posyandu. Pihak Puskesmas mencari faktor utama penyebab kejadian abortus pada ibu hamil.

\section{G. Referensi}

Ahmad S.2008.Profil Kesehatan Indonesia 2007. DepKes RI.Jakarta. Available online: www.depkes.go.id. 5 April 2009

Bobak, Lowdermilk, Jensen. (2004). Buku Ajar Keperawatan Maternitas. Edisi 4 Alih Bahasa oleh Maria A. Wijayarini dan Peter I Anugrah. Jakarta: Penerbit Buku Kedokteran ECG.

Cunningham. (2005). Obstetri Williams. Jakarta : RCG

Depkes R1. 2003- Inclikator Indonesia Sehat 2010. Jakarta

Handayani, D. (2006). Abortus, Cari Penyebab. http://www.jawapos.com/fndeks hnp://strategihr.insannusantara.com /2010/04/upah-minimum-regional2011-berapayah/Kementerian Tenaga Kerja dan Transmigrasi (Kemenakertrans)
Berdasarkan hasil penelitian abortus yang terjadi pada paritas resiko tinggi seperti primipara atau grande para disebabkan oleh kuranngnya asuhan obstretriyang baik selama kehamilan . (Mursyida : 2011)

Ida Bagus Gede Manuaba. (1998). Emu kebidanan Penyakit Kandungan dan Keluarga Berencana Untuk Pendidikan Bidan, Edisi I. Jakarta : EGC

Martaadisoebrata, D.(1982). Obstetri Sosial. Bagianstetri dan inekologiFakultas Kedokteran Universitas Padjadjaran Bandung. Bandung. ElstarOffset.

Multazamiah, (2003). Hubungan Usia Ibu > 35 Tahun Dengan Kejadian Abortus di Ruangan C, (Kebidanan) RSUD Dr. M. Yunus Bengkulu, Tahun 2003, Skripsi Akademi Kebidanan : Poltekkes Bengkulu

Notoatmodjo, S. (2002). Metode penelitian Kesehatan. Jakarta: Rineka Cipta.

Notoatmodjo, S. (2010). Jakarta : Rineka Cipta.

Prawiroharjo. (1999). Pelayanan Kesehatan Maternal dan Dan Sikonatal. Jakarta: ayasan Wina Pustaka.

Saifudin. (2002). Peranan Kesehatan Maternal dan Neonatal. Jakarta : Yayasan Bina Pustaka.

Sarwono. (1999). Ilmu Kebidanan. Jakarta: Yayasan Bina Pustaka Sarwono.

Sarwono. (2008). Ilmu Kebidanan. Jakarta : Yayasan Bina Pustaka, Sarwono. 